\title{
Risiko Kestabilan Lereng Akibat Gempabumi (Studi Area di Kecamatan Patuk, Kabupaten Gunungkidul)
}

(The Risk of slope Stability due to earthquake (case area in patuk district, Gunung Kidul Regency))

\author{
EKA PRIANGGA, SUBAGYO PRAMUMIDJOJO, IMAN SATYARNO
}

\begin{abstract}
The research about risk of slope stability as an effort to mitigate landslide slopes due to the earthquake, based on the earthquake of Jogja 2006 along the Opak River fault. The methods used in this study refers to the PERKA BNPB number 2 of 2012, which conducts a qualitative assessment of the landslide control parameters. Slope stability test is done as an effort to see the effect from earthquake to slope using SLOPE / W software. Test results at 3 locations, each slope in a stable state under normal conditions without earthquake. The first slope (1) in Patuk village has a value ofsafety factor is 2.45 , while in earthquake condition has safety factor number is 1.27 . The value of the safety factor on the second slope (2) in Ngoro-oro village under normal condition safety factor is 2.22 and the earthquake condition has value safety factor is 0.74 . The third slope (3) in Ngoro-oro village has a safety factor number is 3.62 while in earthquake condition has value 1.95 . The result of landslide risk calculation use first (1) scenario in Patuk sub-district generally has medium class, with yellow color in landslide risk map. Patuk villages has high class level for landslide risk map, meanwhile Terbah and Semoyo villages have low level class for landslide risk map. The slope in Patuk sub-district has stable conditions againts earthquake, but the change from slope material caused by weathering can made trigger landslide in future.
\end{abstract}

Keywords: Landslide risk map, AHP, SLOPE/W

\section{PENDAHULUAN}

Longsor yang terjadi akibat gempabumi disebabkan oleh adanya pengaruh kuat magnitudo, durasi guncangan, nilai $P G A$ lokasi, dan sumber gempa (Keefer, 1984) (Meunier, 2007). Kejadian gempabumi di Yogyakarta tahun 2006 silam menimbulkan longsor di sepanjang sesar Kali Opak yang berada di perbatasan Bantul dan Gunungkidul. Bergeraknya massa penyusun lereng di sepanjang sesar Kali Opak ini diakibatkan oleh adanya kekar-kekar pada batuan sehingga melemahkan batuan penyusun lereng (Karnawati, 2007).

Sopheap (2007) dan Saputra, et.al (2016) telah melakukan penelitian tentang perhitungan tingkat risiko longsor di sepanjang sesar Kali Opak. Dalam penelitian ini akan dilakukan perhitungan tingkat risiko longsor akibat gempabumi sebagai upaya dalam mitigasi bencana longsor di Kabupaten Gunungkidul, terutama Kecamatan Patuk. Keadaan geografis yang memiliki lereng curam di sebelah barat maupun utara di Kecamatan Patuk dapat mewakili kondisi penelitian tentang longsor.

\section{Lokasi penelitian}

Kecamatan Patuk, Kabupaten Gunungkidul memiliki luas area $72,52 \mathrm{~km}^{2}$ yang terbagi atas 11 desa (Gambar 1). Kenampakan kondisi google earth menunjukkan bagian Utara dan Barat memiliki kondisi lereng curam $\left(>30^{\circ}\right)$, sedangkan bagian Selatan relatif lebih landai $\left(8^{0}\right)$.

Kenampakan garis kontur pada Gambar 2 menujukkan ketinggian berkisar 600 meter di atas permukaan laut dan terendah 85 meter di atas permukaan laut. Kenampakan kelurusan sesar regional terlihat melalui kenampakan garis kontur dengan arah kelurusan sama di bagian Utara maupun Barat Kecamatan Patuk. 


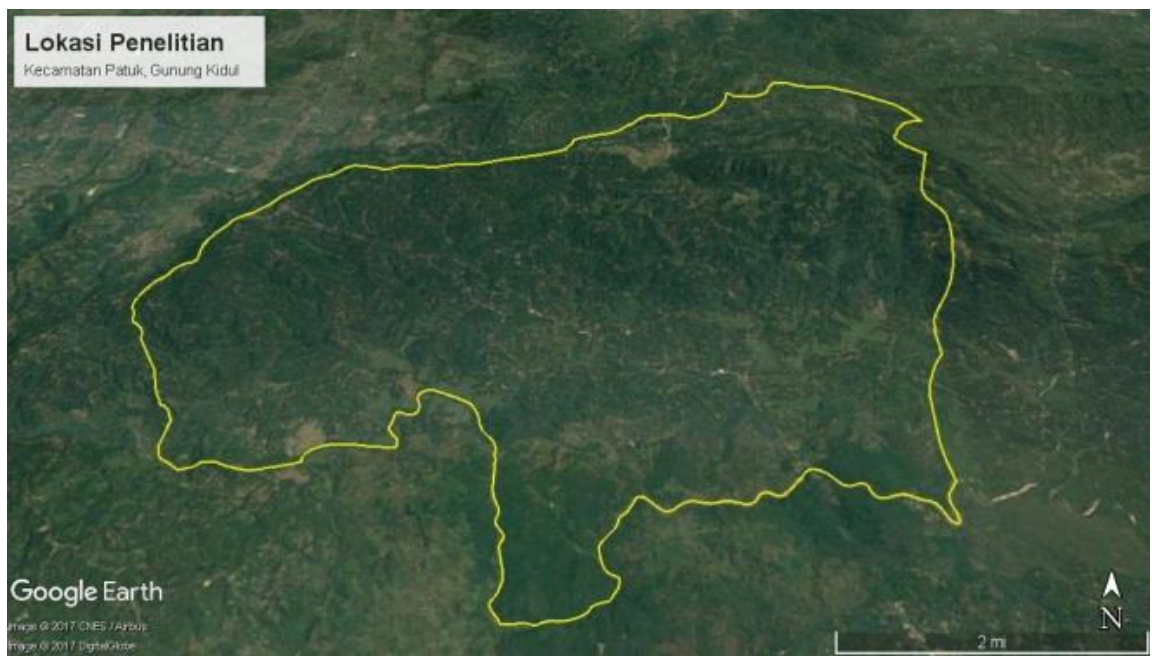

GAMBAR 1. Lokasi penelitian di Kecamatan Patuk, Kabupaten Gunungkidul (googleearth.com)

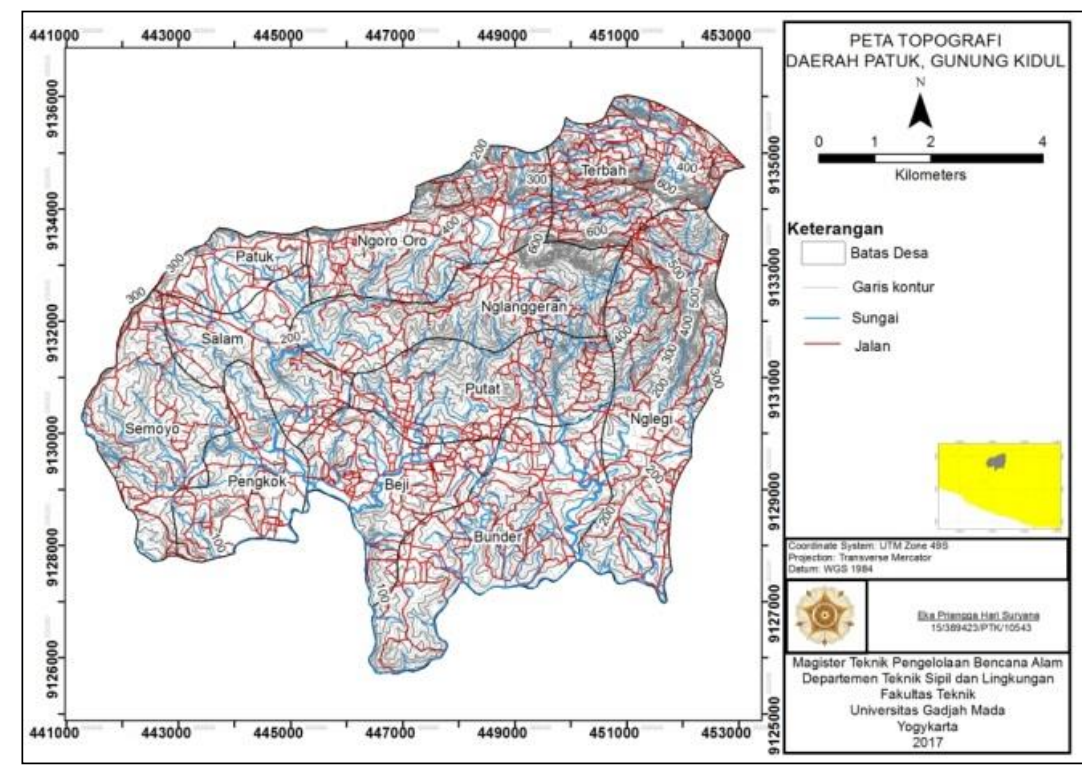

GAMBAR 2. Peta kontur Kecamatan Patuk, Kabupaten Gunungkidul

\section{Geologi Kecamatan Patuk, Kabupaten Gunungkidul}

Berdasarkan data pengamatan lapangan dengan mengacu pada peta geologi regional lembar Yogyakarta yang dibuat oleh Rahardjo et. al (1995), geologi Kecamatan Patuk terbagi atas 5 satuan batuan sebagai berikut ini.

\section{Satuan tuff Semilir}

Terdiri atas batuan tuff yang menempati $12 \%$ dari luasan daerah penelitian. Ciri khusus dari satuan ini adalah tuff dengan fragmen debu halus $(1 / 64 \mathrm{~mm})$ berwarna putih cerah yang dijumpai di sebelah Utara Kecamatan Patuk, seperti Desa Nglegi bagian Utara dan Desa Ngoro-oro bagian Timur laut.
2. Satuan tuff Nglanggeran

Ciri dari satuan ini adalah tuff dengan warna abu-abu tersusun secara tidak seragam dengan ukuran yang berbeda dari halus hingga kasar (1/64mm-1/125mm). Satuan ini dapat dijumpai di sebelah Barat berbatasan langsung dengan tuff Semilir dan Breksi Nglanggeran, menempati 45\% dari luas area penelitian, antara lain Desa Patuk, Desa Semoyo, Desa Salam, dan Desa Beji.

3. Satuan breksi Nglanggeran

Satuan ini dijumpai di Desa Nglanggeran, tepatnya di situs Gunung api purba Nglanggeran. Ciri yang dapat menjadi petunjuk adalah breksi dengan warna abuabu cerah berukuran fragmen berangkal 
hingga bongkah (64mm - >125mm). Fragmen pada breksi tersusun atas andesit serta matriks bersifat non-karbonatan. Diperkirakan batuan berasal dari sumber Gunungapi purba Nglanggeran pada fase erupsi yang sama dengan satuan tuff Nglanggeran.

4. Satuan batupasir Sambipitu

Satuan ini dijumpai di bagian selatan Kecamatan Patuk dengan luas 21\%, tepatnya di Desa Nglegi bagian Selatan dan Desa Bunder. Ciri dari satuan ini berupa batupasir warna putih cerah dengan gradasi ukuran butir relatif besar di sebelah Utara, sedangkan di bagian selatan menjadi halus. Matriks tuff juga dijumpai pada satuan batupasir ini sehingga bisa diperkirakan satuan batuan ini terbentuk pada lingkungan darat.

5. Satuan gamping Wonosari

Satuan ini dicirikan dengan warna putih segar dengan sisipan tuff. Berada di Desa Bunder sepanjang sungai menempati luas $12 \%$ dari lokasi penelitian, memiliki kemiringan batuan berarah Selatan dengan rata-rata bidang perlapisan $\mathrm{N} 123^{\circ} \mathrm{E} / 12^{\circ}$. Satuan ini menjadi penanda lingkungan pengendapan transisi dari lingkungan darat ke laut dangkal.

Sebaran satuan batuan serta struktur geologi hasil pengamatan di lapangan dapat dilihat pada Gambar 3.

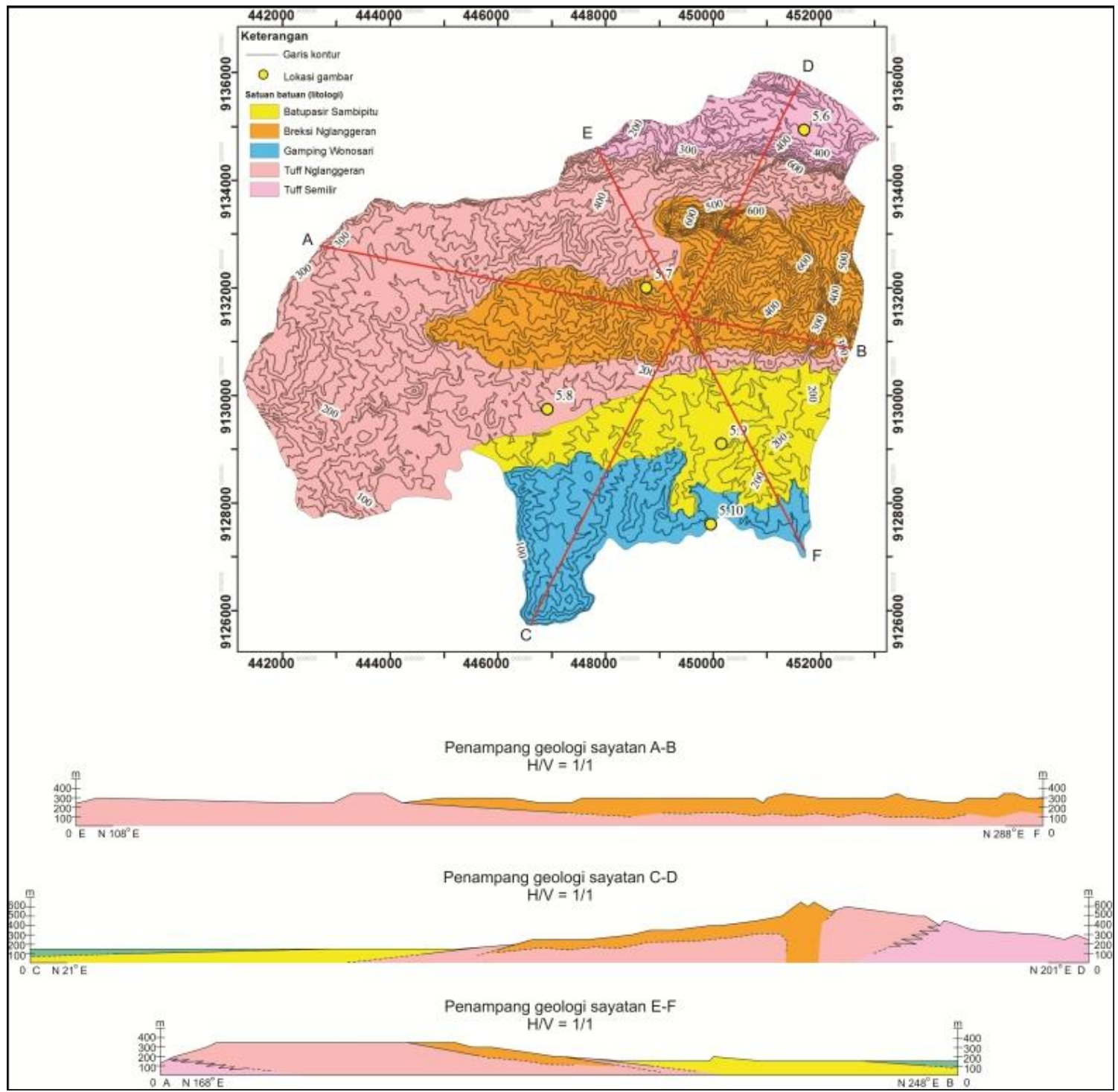

GAMbAR 3. Peta geologi lokal Kecamatan Patuk, Kabupaten Gunungkidul 


\section{Metode Penelitian}

Penelitian mengenai tingkat risiko longsor akibat gempabumi berdasarkan perhitungan skor mengacu pada PERKA BNPB nomor 2 tahun 2012. Tingkat risiko dihitung melalui perkalian antara tingkat kerawanan longsor dengan tingkat kerentanan masyarakat (Persamaan 1).

$$
R S I=\sum H S I \times \sum V S I
$$

Skor dari tingkat kerawanan maupun kerentanan didapatkan dari perkalian antara tingkat kelas parameter dengan nilai bobotnya. Nilai angka bobot parameter didapatkan menggunakan perhitungan sistem AHP (Analytical Hierarchy Process) yang menunjukkan tingkat prioritas parameter pengaruh longsor. Perhitungan tingkat kerawanan longsor dan kerentanan masyarakat dapat dilihat pada Persamaan 2 dan 3.

$$
\begin{aligned}
& \sum H S I=S H I \times W H I \\
& \sum V S I=S V I \times W V I
\end{aligned}
$$

HSI adalah skor indeks kerawanan, merupakan indeks total dari kerawan longsor di suatu daerah. SHI adalah indeks kelas kerawanan, nilai kelas parameter kerawanan longsor. WHI adalah indeks bobot kerawanan longsor. VSI adalah indeks skor kerentanan masyarakat, merupakan indeks total kerentanan wilayah terhadap bencana longsor. SVI adalah indeks kelas kerentanan masyarakat, nilai kelas setiap parameter kerentanan masyarakat. WVI adalah indeks bobot parameter kerentanan masyarakat.

Kekuatan batuan penyusun lereng dari 3 lokasi dihitung menggunakan kriteria keruntuhan batuan Hoek\&Brown (2012). Uji kestabilan lereng dilakukan untuk melihat pengaruh gempabumi terhadap lereng. Perangkat lunak SLOPE/W digunakan dalam proses perhitungan nilai angka aman lereng dengan metode Morgenstein-price serta bidang gelincir block specified.

\section{HASIL DAN PEMBAHASAN}

\section{Gempabumi}

Penilaian pengaruh gempabumi terhadap lereng longsor dihitung menggunakan nilai $P G A$ permukaan, mengingat kejadian gempa memiliki kala ulang yang panjang dan tidak bisa diprediksi.

Nilai $P G A$ pada tubuh batuan didapatkan melalui perhitungan dari kalkulator $P G A$ desain spektra (PUSKIM, 2017). Jenis tanah penyusun sebagai dasar penentuan koefisen $P G A$ permukaan menggunakan uji tanah oleh Pratiknyo (2008) dan perhitungan rerata SPT berdasarkan SNI 4153-2008 menghasilkan nilai $N-S P T>50$, sehingga masuk dalam tipe Sc.

Sebaran $P G A$ di permukaan $\left(P G A_{\mathrm{M}}\right)$ merupakan hasil dari perkalian nilai koefisien $P G A\left(F_{P G A}\right)$ dengan $P G A$ pada batuan dasar yang dapat dilihat pada Gambar 4.

\section{Curah hujan}

Pengaruh air pada proses terjadinya longsor memiliki tingkat cukup tinggi, mengingat air dapat menurunkan kemampuan daya dukung material penyusun lereng. Air dapat masuk ke dalam rekahan batuan baik dari sesar maupun kekar pada batuan penyusun lereng.

Pengaruh air pada tingkat kerawanan longsor berupa curah hujan dan jarak dari sungai. Curah hujan dihitung berdasarkan nilai ratarata curah hujan tahunan selama 10 tahun pada 4 stasiun hujan berpengaruh. Hasil dari perhitungan rerata 4 stasiun memiliki nilai curah hujan $<2000 \mathrm{~mm}^{3} /$ tahun. Sebaran nilai curah hujan rata-rata tahunan pada Kecamatan Patuk dapat dilihat pada Gambar 5.

Lereng yang berbatasan langsung dengan sungai akan memiliki kelembaban tinggi sehingga daya dukung material pada bagian bawah lereng menjadi lemah dan terjadi longsor. Pengaruh sungai pada penyebab longsor dihitung berdasarkan jarak dari sungai terhadap lereng. Jarak dari sungai berdasarkan interval jarak setiap 25 meter, sehingga semakin dekat dengan sungai nilai kelas juga akan meningkat.

\section{Tingkat kerawanan longsor}

Tingkat kerawanan longsor dihitung melalui perkalian antara parameter pengaruh longsor dengan nilai bobot parameternya. Penelitian ini menggunakan 2 skenario untuk tingkat kerawanan longsor dengan rincian mengacu pada Tabel 1 dan 2. Skenario 1 menggunakan seismisitas sebagai pemicu terjadinya longsor dan skenario 2 menggunakan curah hujan sebagai pemicu longsor. 
Tabel 1. Parameter tingkat kerawanan longsor skenario pertama (1)

\begin{tabular}{|c|c|c|c|}
\hline Parameter & Kelas & $\begin{array}{c}\text { Klas } \\
\text { Angk } \\
\mathbf{a} \\
\end{array}$ & $\begin{array}{l}\text { Bobo } \\
\text { t }(\%)\end{array}$ \\
\hline \multirow{4}{*}{$\begin{array}{l}\text { Kemiringan } \\
\text { lereng }\end{array}$} & $0^{0}-8^{0}$ & 1 & \multirow{4}{*}{0.292} \\
\hline & $8^{0}-15^{0}$ & 2 & \\
\hline & $15^{0}-25^{0}$ & 3 & \\
\hline & $25^{0}-45^{0}$ & 4 & \\
\hline \multirow{5}{*}{ Litologi } & $\begin{array}{l}\text { Breksi } \\
\text { Nglanggeran } \\
\end{array}$ & 1 & \multirow{5}{*}{0.079} \\
\hline & Tuff Semilir & 2 & \\
\hline & $\begin{array}{l}\text { Tuff } \\
\text { Nglanggeran }\end{array}$ & 2 & \\
\hline & $\begin{array}{l}\text { Batugamping } \\
\text { Wonosari }\end{array}$ & 2 & \\
\hline & $\begin{array}{l}\text { Batupasir } \\
\text { Sambipitu } \\
\end{array}$ & 2 & \\
\hline \multirow{5}{*}{ Relief } & $75-145$ meter & 1 & \multirow{5}{*}{0.053} \\
\hline & $145-215$ meter & 2 & \\
\hline & $215-285$ meter & 3 & \\
\hline & $285-355$ meter & 4 & \\
\hline & $>355$ meter & 5 & \\
\hline \multirow{3}{*}{$\begin{array}{l}\text { Seismisitas } \\
(P G A)\end{array}$} & $<0,26 \mathrm{~g}$ & 1 & \multirow{3}{*}{0.296} \\
\hline & $0,26 g-0,70 g$ & 2 & \\
\hline & $>0,70 \mathrm{~g}$ & 3 & \\
\hline \multirow{3}{*}{$\begin{array}{l}\text { Kerapatan } \\
\text { Struktur }\end{array}$} & Rendah & 1 & \multirow{3}{*}{0.163} \\
\hline & Sedang & 2 & \\
\hline & Tinggi & 3 & \\
\hline \multirow{5}{*}{$\begin{array}{l}\text { Jarak dari } \\
\text { Lineament }\end{array}$} & $<50$ meter & 5 & \multirow{5}{*}{0.118} \\
\hline & $50-100$ meter & 4 & \\
\hline & $100-150$ meter & 3 & \\
\hline & $150-200$ meter & 2 & \\
\hline & $>200$ meter & 1 & \\
\hline
\end{tabular}

Tabel 2. Parameter tingkat kerawanan longsor skenario kedua (2)

\begin{tabular}{|c|c|c|c|}
\hline Parameter & Kelas & $\begin{array}{c}\text { Klas } \\
\text { Angka }\end{array}$ & $\begin{array}{l}\text { Bobot } \\
(\%)\end{array}$ \\
\hline \multirow{4}{*}{$\begin{array}{l}\text { Kemiringan } \\
\text { lereng }\end{array}$} & $0^{0}-8^{0}$ & 1 & \multirow{4}{*}{0.338} \\
\hline & $8^{0}-15^{0}$ & 2 & \\
\hline & $15^{0}-25^{0}$ & 3 & \\
\hline & $25^{0}-45^{0}$ & 4 & \\
\hline \multirow{5}{*}{ Litologi } & $\begin{array}{l}\text { Breksi } \\
\text { Nglanggeran }\end{array}$ & 1 & \multirow{5}{*}{0.071} \\
\hline & Tuff Semilir & 2 & \\
\hline & $\begin{array}{l}\text { Tuff } \\
\text { Nglanggeran }\end{array}$ & 2 & \\
\hline & $\begin{array}{l}\text { Batugamping } \\
\text { Wonosari }\end{array}$ & 2 & \\
\hline & $\begin{array}{l}\text { Batupasir } \\
\text { Sambipitu }\end{array}$ & 2 & \\
\hline \multirow{5}{*}{ Relief } & $75-145$ meter & 1 & \multirow{5}{*}{0.071} \\
\hline & $145-215$ meter & 2 & \\
\hline & $215-285$ meter & 3 & \\
\hline & $285-355$ meter & 4 & \\
\hline & $>355$ meter & 5 & \\
\hline \multirow{3}{*}{$\begin{array}{l}\text { Curah } \\
\text { hujan }\end{array}$} & $\begin{array}{l}<2000 \\
\mathrm{~mm} / \text { tahun }\end{array}$ & 1 & \multirow{3}{*}{0.252} \\
\hline & $\begin{array}{l}2000-3000 \\
\mathrm{~mm} / \text { tahun }\end{array}$ & 2 & \\
\hline & $\begin{array}{l}3000 \\
\mathrm{~mm} / \text { tahun }\end{array}$ & 3 & \\
\hline \multirow{3}{*}{$\begin{array}{l}\text { Kerapatan } \\
\text { Struktur }\end{array}$} & Rendah & 1 & \multirow{3}{*}{0.132} \\
\hline & Sedang & 2 & \\
\hline & Tinggi & 3 & \\
\hline \multirow{5}{*}{$\begin{array}{l}\text { Jarak dari } \\
\text { Sungai }\end{array}$} & $<25$ meter & 5 & \multirow{5}{*}{0.132} \\
\hline & $25-50$ meter & 4 & \\
\hline & $50-75$ meter & 3 & \\
\hline & $75-100$ meter & 2 & \\
\hline & $>100$ meter & 1 & \\
\hline
\end{tabular}




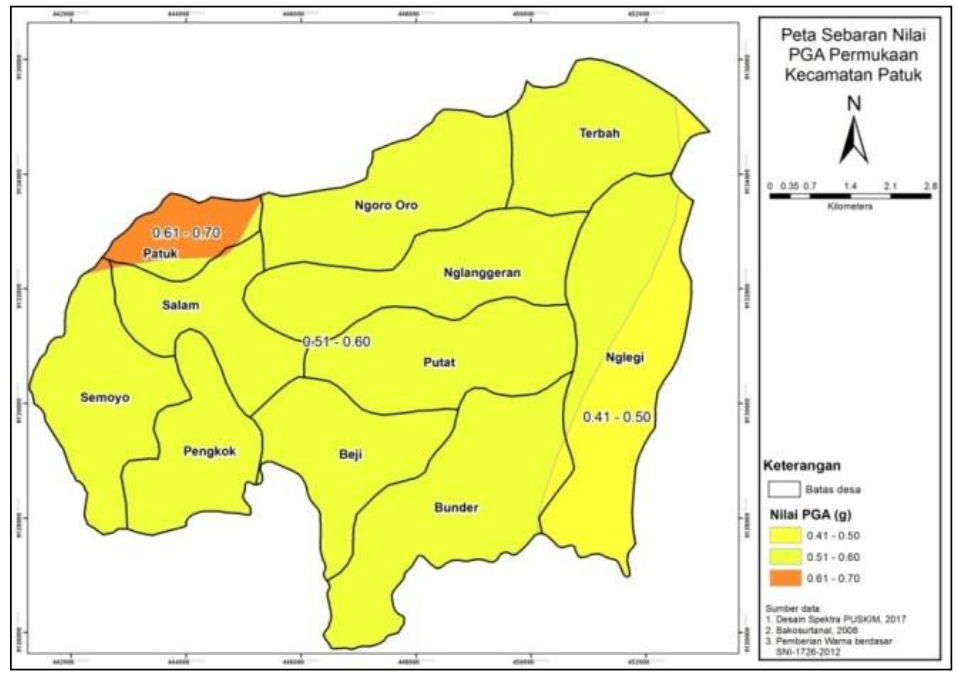

GAMBAR 4. Peta seismisitas $P G A_{M}$ di Kecamatan Patuk, Kabupaten Gununugkidul

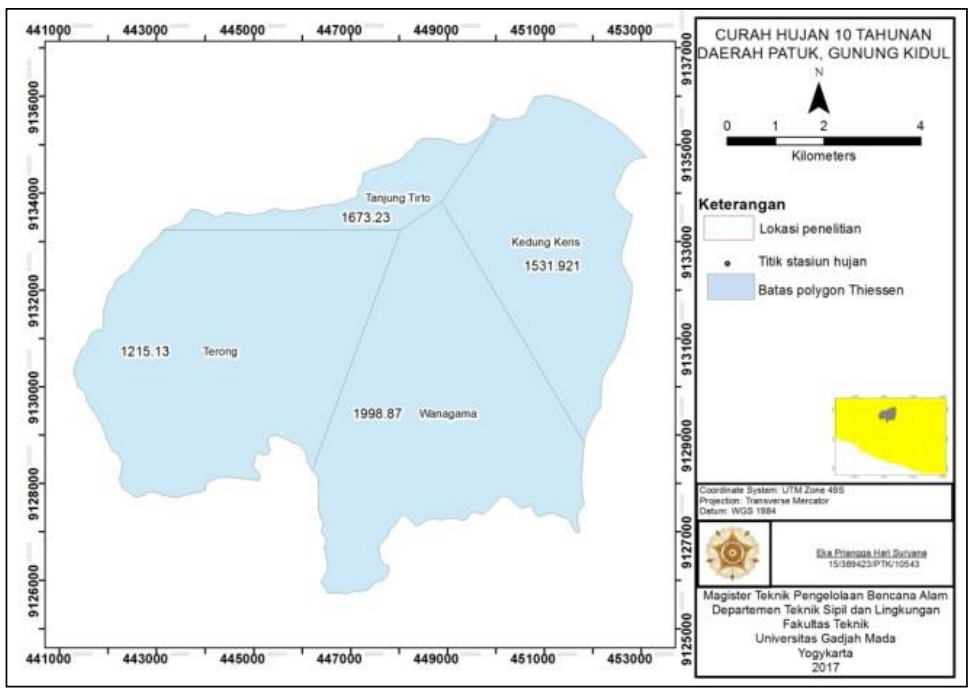

GAMBAR 5. Peta nilai rata-rata tahunan curah hujan

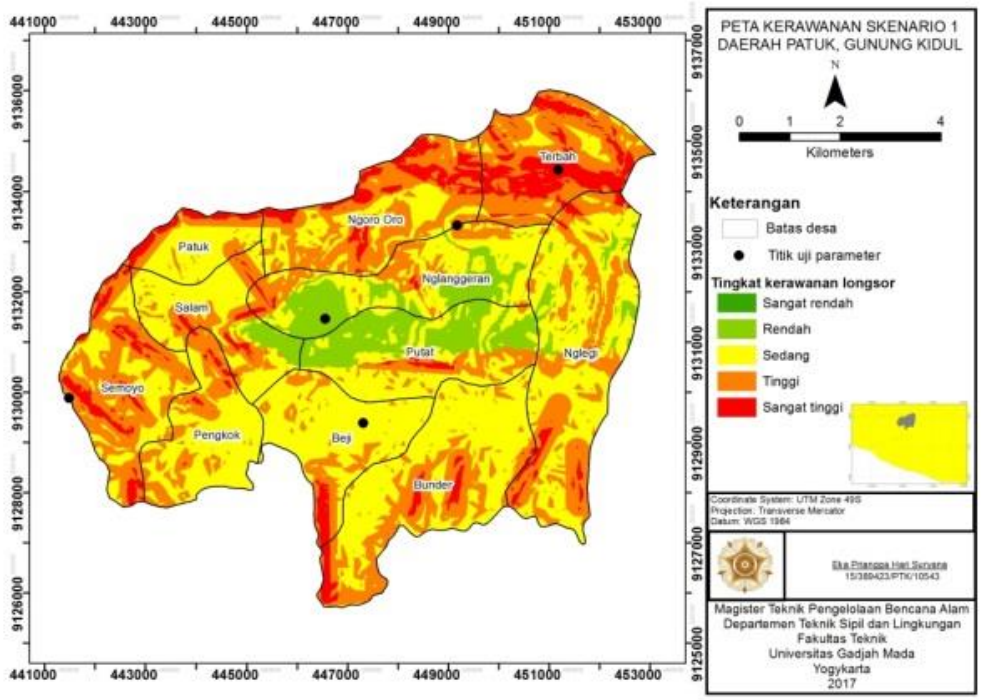

GAMBAR 6. Peta kerawanan longsor skenario pertama (1) 


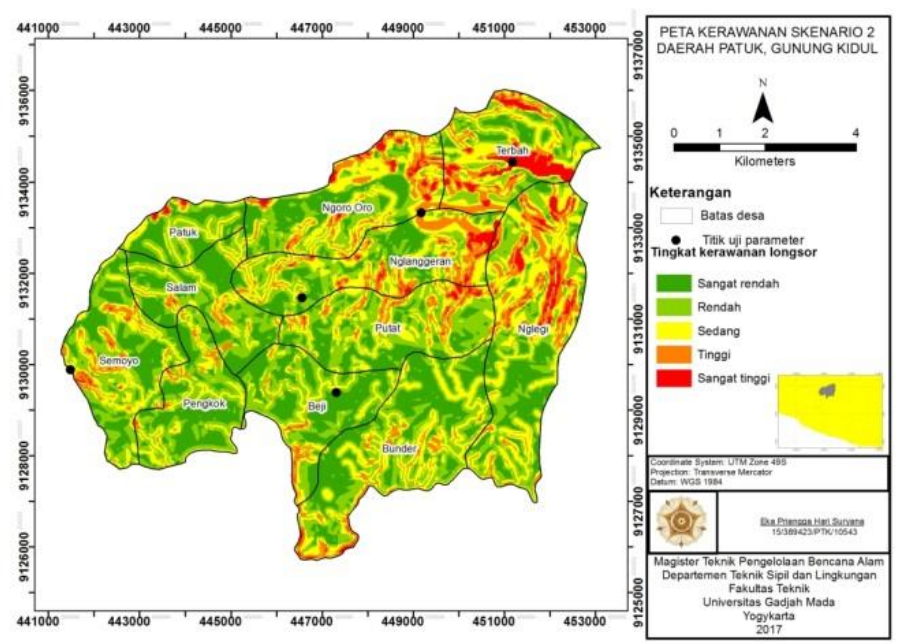

GAMBAR 7. Peta kerawanan longsor skenario kedua (2)

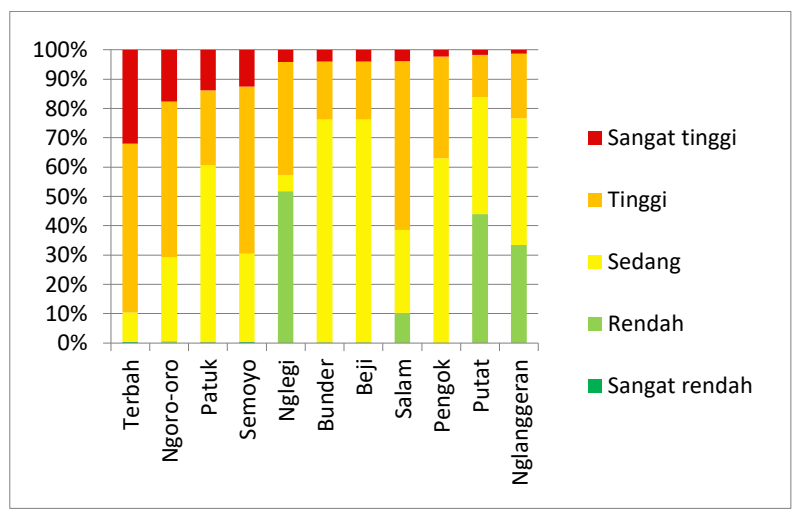

GAMBAR 8. Sebaran tingkat kerawanan longsor menggunakan skenario pertama (1) pada tiap desa di Kecamatan Patuk, Kabupaten Gunungkidul

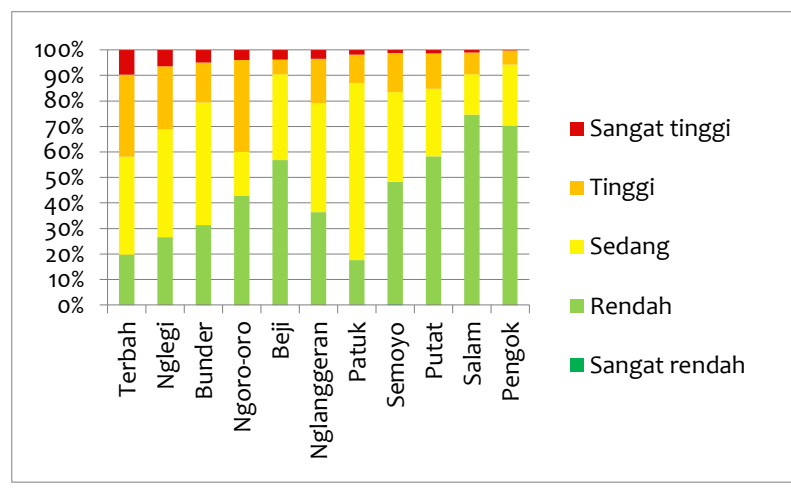

GAMBAR 9. Sebaran tingkat kerawanan longsor menggunakan skenario kedua (2) pada tiap desa di Kecamatan Patuk, Kabupaten Gunungkidul

Hasil dari perhitungan perkalian antara bobot serta nilai kelas kemudian dibagi menggunakan natural breaks (jenks) pada pernagkat lunak GIS. Kerawanan longsor menggunakan skenario 1 dan 2 dapat dilihat pada Gambar 6 dan 7.

Tingkat kerawanan longsor per desa di Kecamatan Patuk, Kabupaten Gunungkidul dengan menggunakan skenario pertama (1), yaitu pengaruh gempabumi ditampilkan pada Gambar 8, sedangkan dengan pengaruh curah hujan dan jarak dari sungai ditampilkan pada Gambar 9.

Terdapat perbedaan tingkat kerawanan menggunakan skenario 1 dan 2. Perbedaan tingkat kerawanan ini diakibatkan oleh adanya nilai bobot pada parameter yang digunakan. Hasil dari perbedaan ini dapat menunjukkan 
pengaruh gempabumi lebih besar berperan daripada curah hujan.

Kelas parameter curah hujan di Kecamatan Patuk bernilai 1 dengan curah hujan berkisar 1800 hingga $1995 \mathrm{~mm} /$ tahun. Nilai bobot untuk curah hujan $25 \%$ dan kemiringan lereng $34 \%$, sehingga bobot pada curah hujan lebih kecil.

Skenario 1 dengan pengaruh seismisitas $(P G A)$ memiliki tingkat sedang untuk sebagian besar tingkat kerawanan di Kecamatan Patuk. Beberapa lokasi yang memiliki tingkat kelereng curam menujukkan warna merah. Parameter siesmisitas memiliki bobot $29 \%$ sementara kemiringan bobot $29 \%$.

\section{Kekuatan batuan}

Pengaruh gempabumi terhadap lereng yang ada di Kecamatan Patuk dipilih 3 lokasi berbeda untuk melihat variasi angka nilai aman. Kekuatan batuan menggunakan metode kriteria Hoek\&Brown dengan langkah perhitungan nilai GSI (Geological Strength Index), nilai D (gangguan material penyusun lereng), nilai konstanta $s, a$, dan $m_{b}$.

Hasil akhir dari perhitungan kriteria Hoek\&Brown menghasilkan nilai kohesi (c) dan sudut gesek dalam ( $\phi)$. Dari proses perhitungan pada 3 lokasi uji kestabilan menghasilkan nilai kohesi $(c)$ dan sudut gesek dalam $(\phi)$ terdapat pada Tabel 3.

\section{Simulasi faktor nilai aman}

Uji kestabilan lereng melalui perhitungan angka aman pada 3 lokasi lereng menggunakan perangkat lunak SLOPE/W. Angka aman menggunakan simulasi perangkat lunak SLOPE/W dengan metode Morgenstein-price menghasilkan nilai sebagai berikut:

\section{a. Lereng pertama (1)}

Berada di Desa Patuk, berbatasan dengan Kecamatan Piyungan dengan kondisi kelerengan miring di jalur Bukit Bintang. Geometri lereng berdasarkan simulasi perangkat lunak didapatkan hasil pada kondisi lereng normal sebagai berikut (Gambar 10).

Hasil angka aman di atas pada kondisi normal, skenario lain juga dihitung menggunakan pengaruh gempa dan air. Hasil perhitungan angka aman menggunakan 2 skenario dan metode lain dapat dilihat pada Tabel 4 .

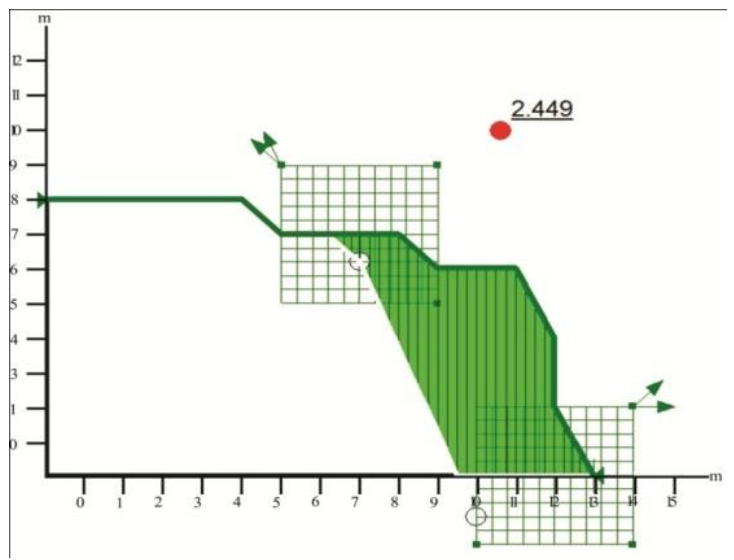

GAMBAR 10. Geometri lereng pertama desa

Patuk beserta nilai faktor aman

Tabel 3. Nilai kohesi dan sudut gesek dalam pada 3 lokasi uji lereng

\begin{tabular}{llcc}
\hline Lokasi & Desa & Sudut gesek $(\phi)$ & Kohesi $(c)$ \\
\hline Lereng 1 & Patuk & 60,903 & 28,393 \\
\hline Lereng 2 & Ngoro-oro & 67,987 & 7,247 \\
\hline Lereng 3 & Ngoro-oro & 62,129 & 8,651 \\
\hline
\end{tabular}

Tabel 4.Nilai faktor aman lereng pertama (1) di Desa Patuk

\begin{tabular}{lccc}
\hline \multirow{2}{*}{ Metode } & \multicolumn{3}{c}{ Nilai Faktor Aman } \\
\cline { 2 - 4 } & Normal & Gempa & Gempa+Air \\
\hline Morgeinsten-price & 2,449 & 1,271 & 0,895 \\
\hline Bishop & 2,683 & 1,597 & 1,235 \\
\hline Janbu & 2,974 & 1,330 & 1,069 \\
\hline Ordinary & 2,939 & 1,349 & 1,098 \\
\hline
\end{tabular}


b. Lereng kedua (2)

Lokasi lereng kedua berada di Desa Ngorooro, tepatnya di bagian Utara berbatasan dengan lereng curam. Nilai faktor aman menggunakan perangkat lunak SLOPE/W dengan geometri terdapat pada Gambar 11 menghasilkan nilai 3,12. Pengaruh gempa dalam perhitungan menurunkan nilai faktor aman mencapai 1,24, sehingga lereng menjadi kritis.

Hasil dengan metode lain untuk pembanding dengan geometri dan nilai parameter yang sama menghasilkan nilai sesuai pada Tabel 5 .

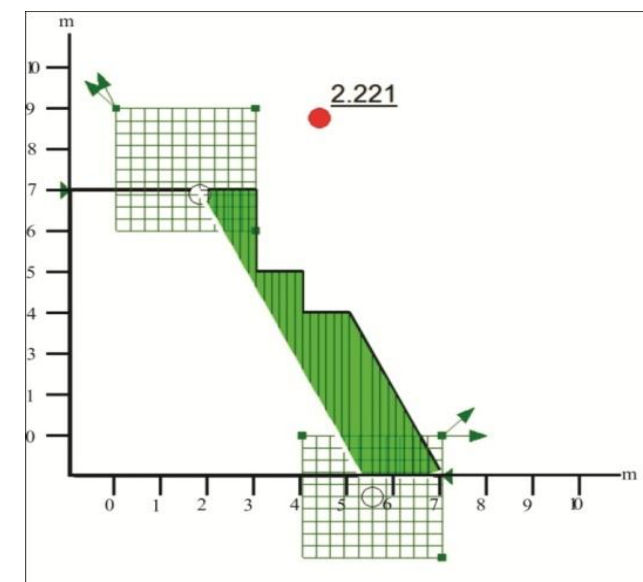

GAMBAR 11. Geometri lereng kedua di desa Ngoro-oro beserta nilai faktor aman c. Lereng ketiga (3)

Lereng ketiga Desa Ngoro-oro terletak di jalan arah menuju Desa Nglanggeran di daerah tower pemancar televisi. Kondisi lereng sesuai pada Gambar 12, dimana bagian atas dari lereng terdapat bangunan tower pemancar televisi serta bagian bawah memiliki tingkat kecuraman yang besar dengan kemiringan sudut mencapai $30^{\circ}$, dimana tertutup oleh pepohonan sehingga bagian bawah sulit untuk dijangkau.

Dengan menggunakan metode lain sebagai pembanding nilai angka aman, dihasilkan nilai seperti pada Tabel 6 .

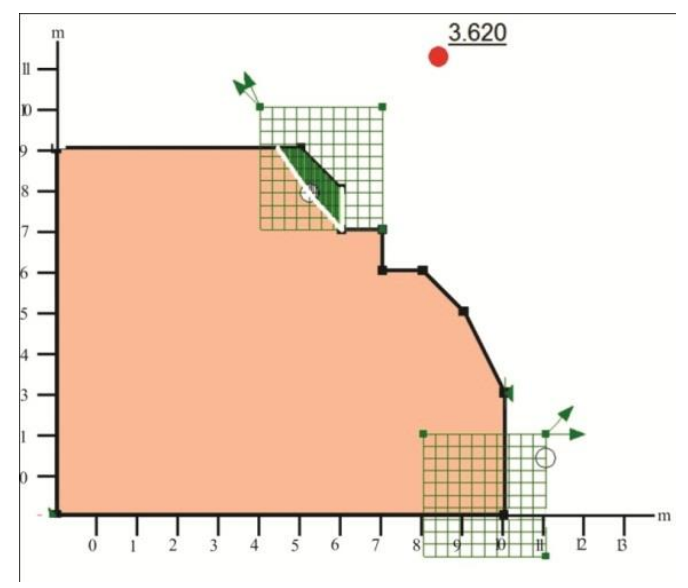

GAMBAR 12. Geometri lereng ketiga di desa Ngoro-oro beserta nilai faktor aman

Tabel 5. Nilai faktor aman lereng kedua (2) di Desa Ngoro-oro

\begin{tabular}{lccc}
\hline \multirow{2}{*}{ Metode } & \multicolumn{3}{c}{ Nilai Faktor Aman } \\
\cline { 2 - 4 } & Normal & Gempa & Gempa+Air \\
\hline Morgeinsten-price & 2,221 & 0,738 & 0,612 \\
\hline Bishop & 1,697 & 1,697 & 0,798 \\
\hline Janbu & 1,872 & 1,872 & 0,539 \\
\hline Ordinary & 1,869 & 1,869 & 0,385 \\
\hline
\end{tabular}

Tabel 6. Nilai faktor aman lereng ketiga (3) di Desa Ngoro-oro

\begin{tabular}{lccc}
\hline \multirow{2}{*}{ Metode } & \multicolumn{3}{c}{ Nilai Faktor Aman } \\
\cline { 2 - 4 } & Normal & Gempa & Gempa+Air \\
\hline Morgeinsten-price & 3,620 & 1,951 & 1,951 \\
\hline Bishop & 3,403 & 2,057 & 2,057 \\
\hline Janbu & 3,656 & 1,930 & 1,93 \\
\hline Ordinary & 2,647 & 1,308 & 1,097 \\
\hline
\end{tabular}




\section{Hubungan antara angka aman dengan gempabumi}

Simulasi angka aman dengan berbagai kondisi nilai PGA permukaan per $0,1 \mathrm{~g}$ dari $0 \mathrm{~g}$ hingga 1g. Penggunaan simulasi dilakukan sebagai upaya melihat pengaruh gempa terhadap nilai angka aman dari ketiga lokasi uji lereng.

Hasil perhitungan angka aman yang terdapat pada Gambar 13 menunjukkan bahwa gempa memiliki pengaruh dalam penurunan nilai angka aman.

Kerentanan masyarakat dihitung melalui perkalian antara nilai kelas parameter dengan nilai bobotnya. Hasil dari penilaian ini berdasarkan data per desa yang ada di Kecamatan Patuk. Parameter yang digunakan beserta bobot dari masing-masing parameternya dapat dilihat pada Tabel 7 .
Kondisi yang terjadi pada gempa Jogja 2006 dengan anggapan bahwa nilai $P G A$ permukaan pada ketiga lokasi secara berurutan $0,6 \mathrm{~g}$, $0,51 \mathrm{~g}$, dan 0,51g. Nilai angka aman tersebut menjadi pembatas dimana lereng dikatakan stabil, jika kejadian gempa dengan kuat magnitudo lebih besar dari 5,9 SR maka akan terjadi longsor pada 3 lokasi lereng.

\section{Tingkat kerentanan masyarakat}

Nilai skor dari kerentanan kemudian dibagi berdasarkan natural breaks (jenks), menghasilkan batas nilai. Kerentanan dibagi menjadi 5 kelas dari tingkat sangat rendah hingga sangat tinggi dalam bentuk warna terdapat pada Gambar 14. Sebaran tingkat kerentanan masing-masing desa di Kecamatan Patuk ditampilkan pada Gambar 15.

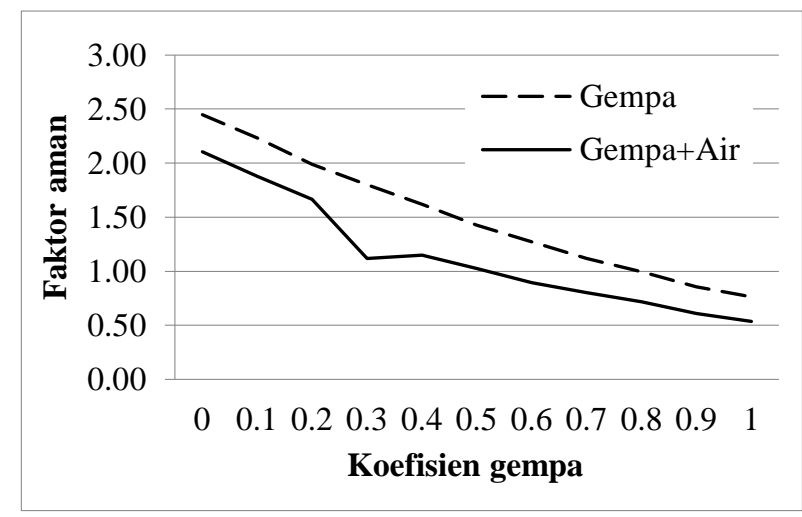

GAMBAR 13. Hubungan nilai faktor aman dengan koefisien gempa

Tabel 7. Parameter tingkat kerentanan masyarakat

\begin{tabular}{|c|c|c|c|}
\hline Parameter & Kelas & Klas Angka & Bobot $(\%)$ \\
\hline \multirow{3}{*}{ Jumlah penduduk } & $<500 \mathrm{jiwa} / \mathrm{km} 2$ & 1 & \multirow{3}{*}{0.4} \\
\hline & $500-1000$ jiwa/km2 & 2 & \\
\hline & $>1000 \mathrm{jiwa} / \mathrm{km} 2$ & 3 & \\
\hline \multirow{3}{*}{ Kelompok rentan } & $<20 \%$ & 1 & \multirow{3}{*}{0.2} \\
\hline & $20-40 \%$ & 2 & \\
\hline & $>40 \%$ & 2 & \\
\hline \multirow{5}{*}{ Tataguna lahan } & Hutan & 1 & \multirow{5}{*}{0.4} \\
\hline & Tegalan & 1 & \\
\hline & Persawahan & 2 & \\
\hline & Kebun & 2 & \\
\hline & Pemukiman & 3 & \\
\hline
\end{tabular}




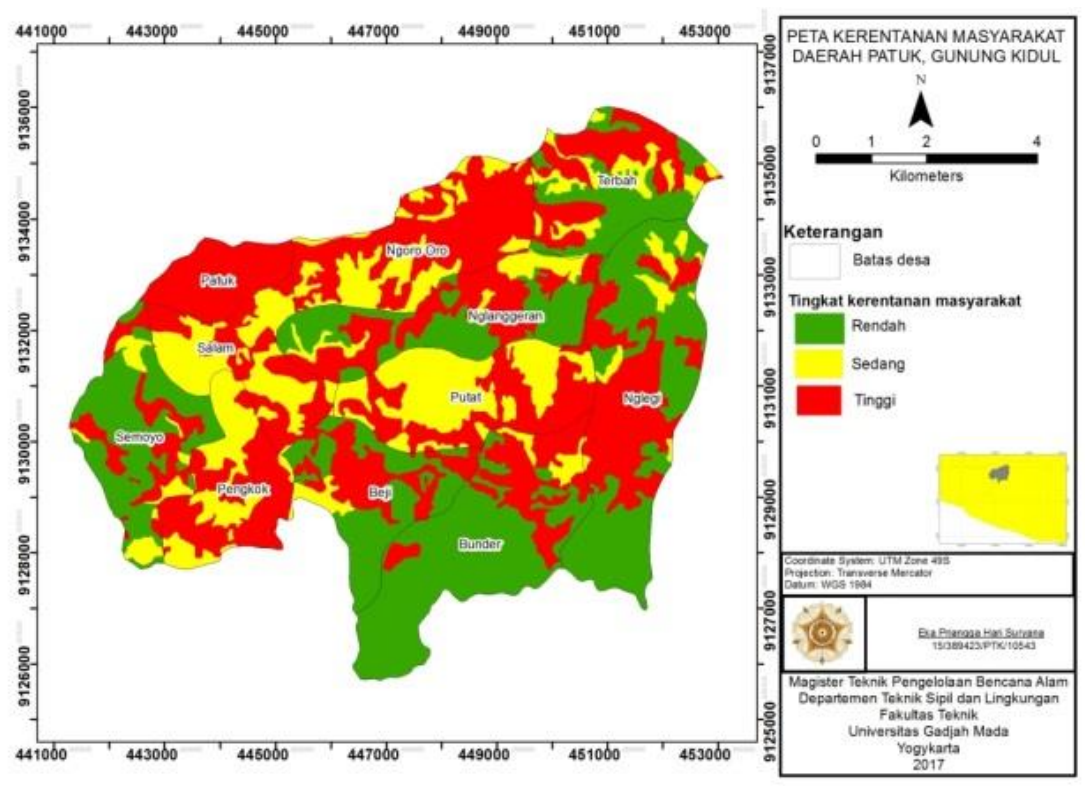

GAMBAR 14. Peta kerentanan masyarakat Kecamatan Patuk, Kabupaten Gunungkidul

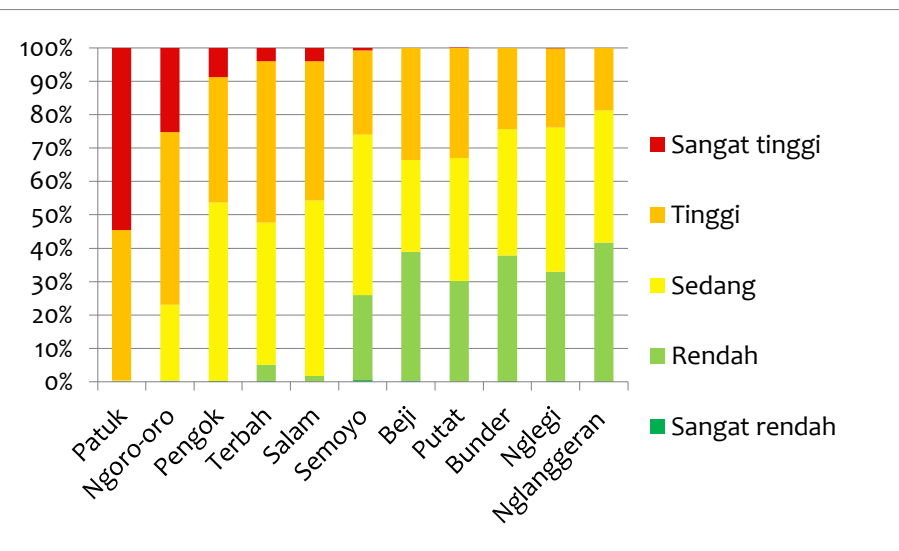

GAMBAR 10. Sebaran tingkat kerentanan masyarakat pada tiap desa di Kecamatan Patuk, Kabupaten Gunungkidul

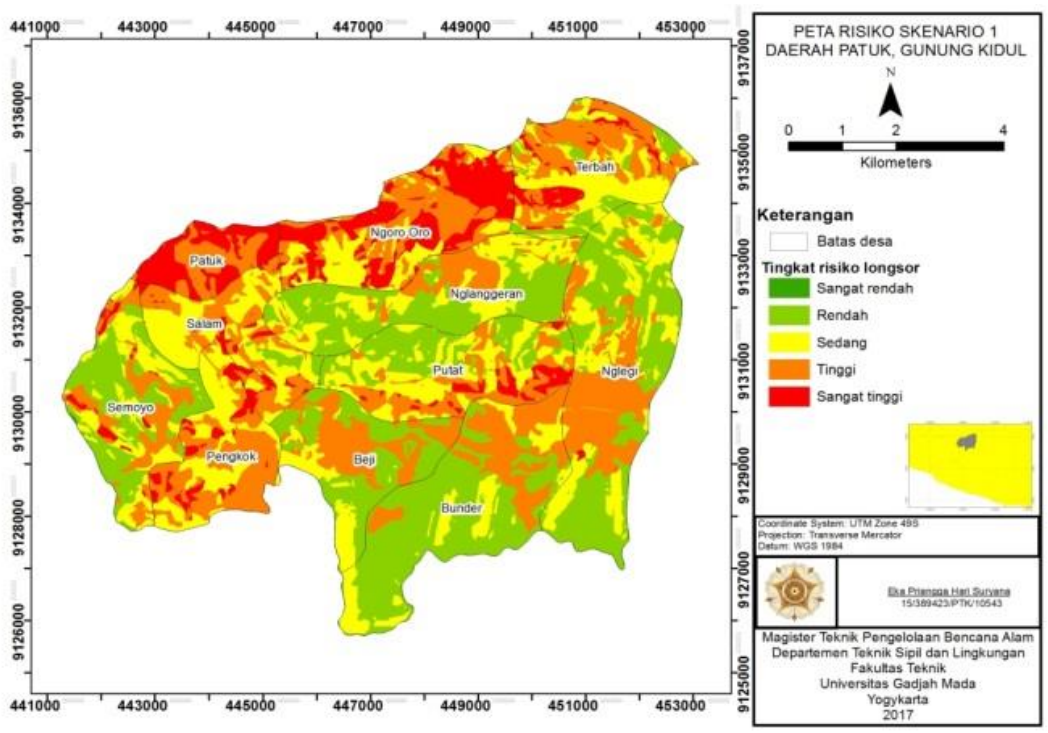

GAMBAR 16. Peta risiko longsor skenario pertama

(1) menggunakan pengaruh gempabumi 


\section{Tingkat risiko longsor}

Risiko longsor adalah hasil perkalian antara tingkat kerawanan longsor dengan tingkat kerentanan. Hasil dari pembuatan peta risiko longsor dengan 2 skenario yakni gempa dan pengaruh air hujan ditampilkan pada Gambar 16 dan Gambar 17. Perbedaan hasil yang diperoleh diakibatkan dari nilai kerawanan longsor yang berbeda pada jumlah parameter yang digunakan serta bobot tiap parameter.

Nilai perkalian yang dibagi menggunakan natural breaks (jenks) akan menghasilkan 5 kelas risiko longsor. Tingkat risiko longsor di Kecamatan Patuk menggunakan skenario pertama (1) dan menggunakan skenario kedua (2) ditampilkan pada Gambar 18 dan Gambar 19.

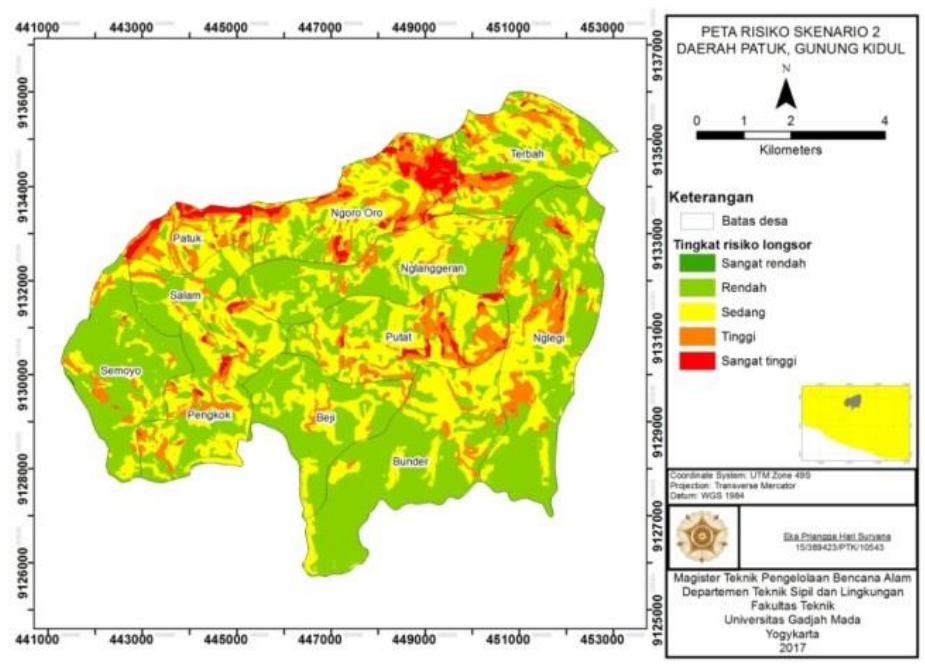

GAMBAR 17. Peta risiko longsor menggunakan skenario kedua (2) dengan pengaruh curah hujan

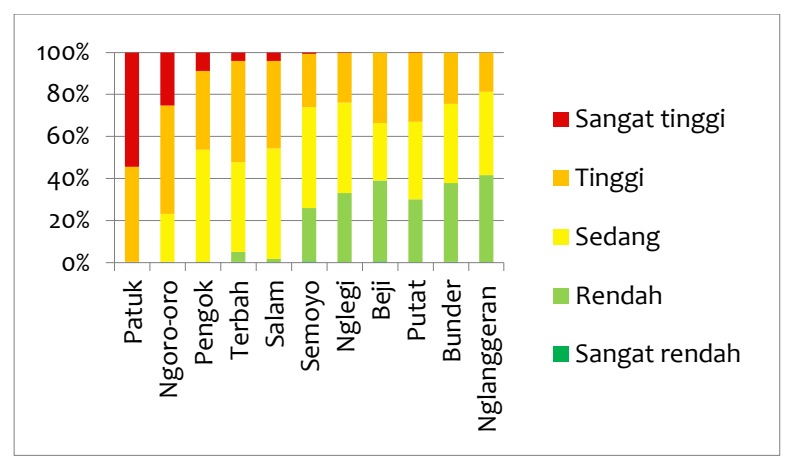

GAMBAR 18. Sebaran tingkat risiko longsor menggunakan skenario pertama (1) pada tiap desa di Kecamatan Patuk, Kabupaten Gunungkidul

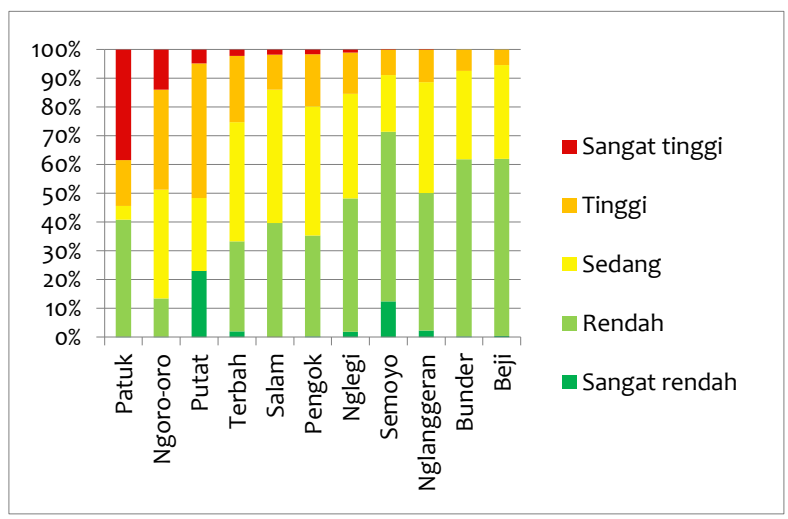

GAMBAR 19. Sebaran tingkat risiko longsor menggunakan skenario kedua (2) pada tiap desa di Kecamatan Patuk, Kabupaten Gunungkidul 


\section{KESIMPULAN}

1. Dari hasil pengujian di 3 lokasi, setiap lereng dalam keadaan stabil dalam kondisi normal tanpa gempa. Nilai faktor aman pada lereng pertama (1) di Desa Patuk sebesar 2,45, pada lereng kedua (2) di Desa Ngoro-oro sebesar 2,22 dan pada lereng ketiga (3) di Desa Ngoro-oro sebesar 3,62.

2. Koefisien gempa mengakibatkan penurunan nilai faktor aman lereng. Pada kondisi gempabumi nilai faktor aman berturut-turut berkurang menjadi sebesar 1,$27 ; 0,74$ dan 1,95 .

3. Hasil perhitungan risiko longsoran menggunakan skenario pertama (1) di Kecamatan Patuk umumnya memiliki kelas menengah. Desa Patuk memiliki risiko longsor tingkat tinggi, sedangkan Desa Terbah dan Semoyo memiliki risiko longsor tingkat bawah.

4. Kemiringan di Kecamatan Patuk memiliki kondisi yang stabil terhadap gempa, tetapi perubahan dari material lereng yang disebabkan oleh pelapukan dapat menyebabkan tanah longsor di masa depan.

\section{DAFTAR PUSTAKA}

Badan Standarisasi Nasional, 2008. SNI 4153:2008 Cara uji penetrasi lapangan dengan SPT. Jakarta: Badan Standarisasi Nasional Badan Standarisasi Nasional.

Chalkias, C., 2014. GIS-BAsed Landslide Susceptibility Mapping on the Peloponesse Peninsula, Greece. Geoscience open access, pp.176 - 190.

Karnawati, D., 2007. Mekanisme Gerakan Massa Batuan Akibat Gempabumi; Tinjauan dan Analisis Geologi Teknik. Dinamika Teknik Sipil, volume 7, nomer 2, pp.179-90.

Keefer, D., 1984. Landslide caused of earthquake. Geological Society of America Bulletin , pp.406 - 421.

Meunier, P., 2007. Regional Patterns of Earthquake-triggered Landslides and
Their Relation to Ground Motion. Geophysical Research Letters Vol.34, p.1.

Pratiknyo, P., 2008. Studi Geologi Teknik Rencana Bendung Karang KecamtanPatu, Kabupaten GunungKidul. Jurnal Ilmiah MTG vol 1, p.10.

Rahardjo, W., Sukandarrumidi \& Rosidi, H.M.D., 1995. Peta geologi lembar Yogyakarta, Jawa. Bandung: P3B.

Saputra, A., Gomez, C., Hadmoko, D.S. \& Sartohadi, J., 2016. Coseismic Landslide Susceptibilty Assessment Using Geographic Informastion System. Geoenvironmental Disasters.

Sopheap, L., 2007. Landslide Risk Assessment at Piyungan-Patuk Area, Yogyakarta Special Region, Indonesia. Yogyakarta: Universitas Gadjah Mada.

Thearit, Y., 2009. Landslide Risk Mapping Using GIS-Based Weighted Linear Combination in Kulon Progo Regency, Yogyakarta Special Province, Indonesia: Universitas Gadjah Mada.

PENULIS:

Eka Priangga Hari Suryana

Program Studi Magister Teknik Pengelolaan Bencana Alam, Departemen Teknik Sipil dan Lingkungan, Universitas Gadjah Mada, Yogyakarta

Email: ekapriangga@gmail.com

Subagyo Pramumidjojo

Program Studi Magister Teknik Pengelolaan Bencana Alam, Departemen Teknik Sipil dan Lingkungan, Universitas Gadjah Mada, Yogyakarta

Iman Satryarno

Program Studi Magister Teknik Pengelolaan Bencana Alam, Departemen Teknik Sipil dan Lingkungan, Universitas Gadjah Mada, Yogyakarta 